\title{
First report of Anaplasma ovis in pupal and adult Melophagus ovinus (sheep ked) collected in South Xinjiang, China
}

\author{
Li Zhao ${ }^{1,2}$, Bo He ${ }^{1}$, Kai-Rui Li', Fei Li ${ }^{1,3}$, Lu-Yao Zhang ${ }^{1}$, Xian-Qiang Li ${ }^{1,2}$ and Yong-Hong Liu ${ }^{1,2^{*}}$
}

\begin{abstract}
Background: Melophagus ovinus (sheep ked) is a blood-feeding ectoparasite that belongs to the family Hippoboscidae (Diptera: Hippoboscoidea) and mainly parasitizes sheep. The life-cycle of M. ovinus consists of three stages: larva, pupa and adult. It has a worldwide distribution and has been found in four provinces of China, especially South Xinjiang. In addition to causing direct damage to animal hosts, $M$. ovinus serves as a vector for disease transmission. In this study, our aim was to investigate the presence of Anaplasma spp. in pupal and adult M. ovinus.

Methods: A total of 93 specimens (including eight pupal specimens) of M. ovinus collected in South Xinjiang were selected for isolation of genomic DNA, followed by PCR amplification and sequencing of the msp4 gene of Anaplasma spp. The sequences were analyzed in MEGA 7.0 software and via online BLAST.

Results: PCR and sequencing results showed that all the specimens collected in 2013 were free of Anaplasma spp., whereas three and 25 specimens (including five pupal specimens) collected in 2016 and 2017, respectively, tested positive for Anaplasma spp. The analysis of $24 \mathrm{msp} 4$ gene sequences (from four pupal specimens) confirmed the presence of A. ovis in M. ovinus specimens collected in South Xinjiang, China. The detected A. ovis isolates belong to Genotypes II and III.

Conclusions: To the best of our knowledge, this is the first report of the detection of A. ovis DNA in pupal M. ovinus, confirming the vertical transmission of A. ovis in M. ovinus and the potential of $M$. ovinus to serve as a vector for A. ovis.
\end{abstract}

Keywords: Melophagus ovinus, Anaplasma ovis, China

\section{Background}

Melophagus ovinus (sheep ked), is a blood-feeding ectoparasite that belongs to the family Hippoboscidae (Diptera: Hippoboscoidea) and has significant economic effects [1, 2]. Melophagus ovinus (Fig. 1a, b) is an approximately 4-6 mm long wingless fly with a small head, strong and sharp mouthparts, an oval or round abdomen, dense bristles on the body surface, and three pairs of legs tipped with claws $[2,3]$.

The life-cycle of M. ovinus consists of three stages: larva, pupa (Fig. 1c) and adult $[1,4]$. Six to eight days after mating,

\footnotetext{
* Correspondence: lyhdky@126.com

${ }^{1}$ College of Animal Science, Tarim University, 705 Hongqiao South Road, Aral 843300, People's Republic of China

${ }^{2}$ Key Laboratory of Tarim Animanl Husbandry Science and Technology of Xinjiang Production \& Construction Corps, 705 Hongqiao South Road, Aral 843300, People's Republic of China

Full list of author information is available at the end of the article
}

the female fly produces larvae that adhere to the body surface of hosts and are ready to pupate into brown pupae within 6-12 hours. After 19-30 days, the pupae develop into adults, which parasitize the body surface of sheep [1].

Melophagus ovinus is widely distributed and has been found in many European, African, Asian, Oceanian, and North American countries [2]. Until now, M. ovinus has been reported to parasitize only sheep and Tibetan antelopes in Xinjiang [2,5], Qinghai $[2,6]$ and Gansu $[3,7]$ in China. Additionally, adult or pupal M. ovinus specimens have been detected on imported sheep and sheep skin and wool during port-quarantine in certain areas of China $[8,9]$.

Melophagus ovinus mainly parasitizes sheep but has also been found to have an expanded host range, which includes goats [10], rabbits (Oryctolagus cuniculus) [1], dogs [11], wild animals [Tibetan antelope [6], European 


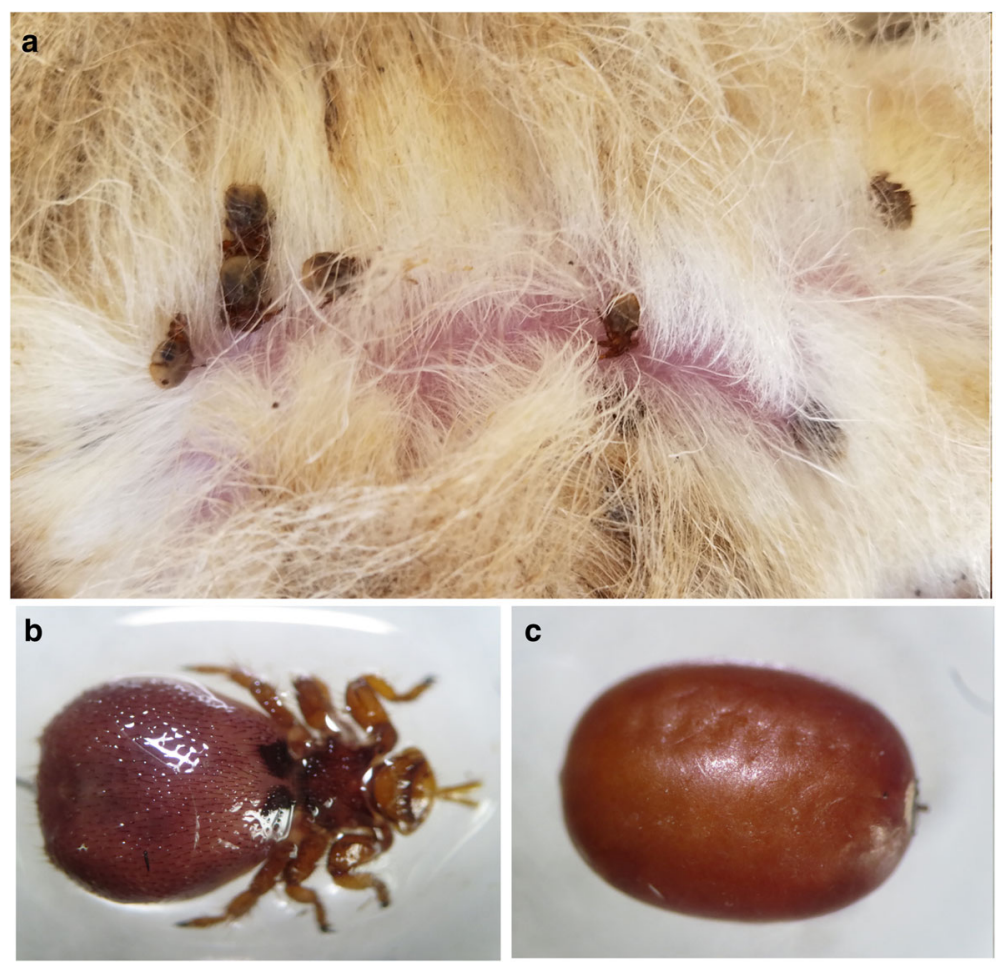

Fig. 1 Sheep from Yahazhen of Kuqa in Xinjiang in June 2017. a. M. ovinus parasitizes sheep in fur. M. ovinus could be found in the fur-covered area all over the body, including ears (and behind the ears), neck, chest, abdomen, back, breech, legs, and tail. b. Adult M. ovinus. c. Pupal M. ovinus

bison (Bison bonasus) [12], and red foxes (Vulpes vulpes) [13]] and humans [11]. It is mainly directly transmitted among sheep during transportation, mixed grazing, sheep crowding, and direct contact between ewes and lambs [14] as well as indirectly transmitted through bedding and tools $[1,7]$.

Upon infection, $M$. ovinus bites and feeds on the blood of sheep, leading to irritation, inflammation, anemia, and subsequently loss of wool, as well as skin damage due to biting, kicking, and rubbing of invaded sites. These actions in turn cause secondary microbial infections or myiasis. Additionally, M. ovinus infestation leads to weight gain and attenuates wool production: effects that compromise the quality and yield of wool as well as the value of sheep skin [1-4]. Moreover, $M$. ovinus serves as an insect vector (or potential vector) for pathogens and has been reported to be responsible for the transmission of e.g. Trypanosoma melophagium [14], Anaplasma ovis [15], blue-tongue virus [16], Bartonella schoenbuchensis, Bartonella chomelii [17], Bartonella melophagi [4, 18] and other Bartonella spp. [19] worldwide. In China, Bartonella garinii, a B. valaisiana-like group [5], Rickettsia raoultii, R. slovaca [2], Bartonella spp., Arsenophonus, Wolbachia [3, 7], Enterobacter, Acinetobacter, Halomonas, Shewanella, Bacillus and Staphylococcus [3] have also been detected in $M$. ovinus. In summary, $M$. ovinus causes huge economic losses either directly or indirectly.

Anaplasma ovis is an obligate intraerythrocytic pathogen infecting sheep, goats, and some wild ruminants [2025]. It belongs to the genus Anaplasma (Rickettsiales: Anaplasmataceae), which has been recently confirmed to include other species responsible for anaplasmosis, such as A. marginale, A. phagocytophilum, A. centrale, A. bovis, $A$. platys and A. capra. Anaplasmosis is an important veterinary and public health issue globally that leads to serious economic losses [25, 26].

The major surface protein 4 (msp4) gene of Anaplasma spp. is highly conserved among many strains [20, 27]. It has been demonstrated that PCR amplification of the msp4 gene has a high diagnostic value for the differential detection of $A$. ovis [20, 22, 28]. The msp 4 gene has also been applied to genetic characterization and phylogenetic studies of Anaplasma spp., thus providing its biogeographic and evolutionary information. Our aim was to investigate the presence of Anaplasma spp. in pupal and adult M. ovinus.

\section{Methods}

Study areas and $M$. ovinus collection

In 2013, five M. ovinus specimens were collected during occasional tick sampling in South Xinjiang and were 
preserved in $70 \%$ ethanol. The sampling locations and time points were not recorded in detail.

In July 2016, 30 experimental specimens preserved in $70 \%$ ethanol were randomly selected from $\sim 300 \mathrm{M}$. ovinus specimens collected from multiple sheep in Yahazhen of Kuqa in Aksu, Xinjiang (1029 m above sea level; 41 $44^{\prime} \mathrm{N}$, $\left.83^{\circ} 14^{\prime} \mathrm{E}\right)$.

In June 2017, over 200 M. ovinus specimens were collected from each of the five sheep in Yahazhen of Kuqa in Aksu, Xinjiang. These M. ovinus specimens were placed in sampling vials with sufficient air and transported immediately to the laboratory for cryopreservation. Ten randomly selected $M$. ovinus specimens from each sheep and eight simultaneously collected pupal $M$. ovinus specimens from three sheep were regarded as experimental specimens.

In this study, $93(5+30+50+8)$ samples were processed individually.

\section{DNA extraction, PCR of the msp4 gene, and sequence analysis}

The 70\% ethanol-preserved $M$. ovinus specimens were washed twice with distilled water after being washed in a graded series of ethanol solutions with concentrations of $50 \%, 30 \%$ and $10 \%$. The cryopreserved adult and pupal M. ovinus specimens were washed twice with distilled water for $1 \mathrm{~h}$ each.

Next, the genomic DNA of $M$. ovinus was extracted using the TaKaRa MiniBEST Universal Genomic DNA Extraction Kit Ver. 5.0 (Takara, Dalian, China, catalogue No. 9765). At the last step, the DNA sample was eluted twice with $50 \mu \mathrm{l}$ of elution buffer, and the resultant $50 \mu \mathrm{l}$ of genomic DNA was stored at $-20{ }^{\circ} \mathrm{C}$ until use.

After that, the msp4 gene of Anaplasma spp., which was PCR-amplified with the KOD-Plus amplification enzyme (Toyobo Co., Ltd., Osaka, Japan) and the Premix $\mathrm{Taq}^{\mathrm{TM}}$ kit (TakaRa Taq $^{\mathrm{TM}}$ Version 2.0; Takara, catalogue No. R004A), was approximately 867 bp.
Each $50 \mu \mathrm{l}$ PCR reaction mixture contained $25 \mu \mathrm{l}$ of the $2 \times$ PCR solution for Premix Taq ${ }^{\mathrm{TM}}, 1 \mu \mathrm{l}$ each of the forward and reverse primers (MSP4-F: 5'-GGG AGC TCC TAT GAA TTA CAG AGA ATT GTT TAC-3'; MSP4-R: 5'-CCG GAT CCT TAG CTG AAC AGG AAT CTT GC-3' [20, 22]), $1 \mu \mathrm{l}$ of the DNA template, and distilled water.

The cycling conditions for the msp4 gene amplification with primers MSP4-F and MSP4-R were as follows: initial denaturation at $94{ }^{\circ} \mathrm{C}$ for $5 \mathrm{~min} ; 40$ cycles at $94{ }^{\circ} \mathrm{C}$ for $30 \mathrm{~s}, 62{ }^{\circ} \mathrm{C}$ for $50 \mathrm{~s}$, and $72{ }^{\circ} \mathrm{C}$ for $1 \mathrm{~min}$; followed by final extension at $72{ }^{\circ} \mathrm{C}$ for $10 \mathrm{~min}$.

All the amplicons were bidirectionally sequenced on an ABI PRISM ${ }^{\text {TM }}$ 3730XL DNA Analyzer (ABI, CarIsbad, America). The sequences were aligned with reference sequences downloaded from GenBank by means of MEGA 7.0 software. The sequences obtained in this study were deposited in the GenBank database under the accession numbers MG283274 and MG564176.

\section{Results}

The msp4 gene of Anaplasma spp. was PCR-amplified and sequenced in samples of the genomic DNA of adult and pupal $M$. ovinus. All five $M$. ovinus specimens collected in 2013 tested negative for Anaplasma spp., three out of the $30 \mathrm{M}$. ovinus specimens collected in 2016 tested positive for Anaplasma spp. with an identical msp4 gene sequence, 20 (collected from two sheep) out of the 50 adult $M$. ovinus specimens collected in 2017 tested positive for Anaplasma spp., and five out of the eight non-blood-feeding pupal $M$. ovinus specimens collected in 2017 tested positive for Anaplasma spp. Anaplasma spp.-positive pupae were produced by adult M. ovinus from the two Anaplasma spp.-positive sheep, whereas three pupae from the other sheep tested negative for Anaplasma spp. There were no differences among the 21 msp4 gene sequences (17 sequences from

Table 1 Sequences relatively closest to the complete msp4 gene sequence of A. ovis detected in the M. ovinus samples from South Xinjiang, China

\begin{tabular}{llll}
\hline Gene & GenBank ID & \% sequence similarity (bp) & Remark \\
\hline MG283274 (A. ovis isolate XJNJ) & A. ovis isolate KS9-b (KJ782401) & $100(852 / 852)$ & China: Xinjiang; 2012; sheep blood \\
& A. ovis isolate YC26 (KJ72404) & $99(851 / 852)$ & China: Xinjiang; 2012; sheep blood \\
& A. ovis isolate ATS20 (KJ782397) & $99(851 / 852)$ & China: Xinjiang; 2012; sheep blood \\
& A. ovis isolate Yongjing (HQ456347) & $99(851 / 852)$ & China: Yongjing County; 2010; sheep blood \\
& A. ovis isolate Italy 20 (KJ782401) & $99(851 / 852)$ & Italy: Sicily; 2004; ovine blood \\
A. ovis isolate MM9 (KY283958) & $99(851 / 852)$ & Turkey: Menemen, Izmir; 2011-2013; sheep blood \\
& A. ovis isolate Yuzhong (HQ456348) & $99(851 / 852)$ & China: Yuzhong County; 2010; sheep blood \\
& A. ovis isolate Italy 147 (AY702924) & $99(851 / 852)$ & Italy: Sicily; 2004; ovine blood \\
A.ovis isolate 395 (KU497698) & $99(851 / 852)$ & Sudan; 2016; sheep \\
A. ovis isolate Yuzhong (LC141088) & $99(850 / 852)$ & Mongolia; 2014; cattle blood \\
\hline
\end{tabular}




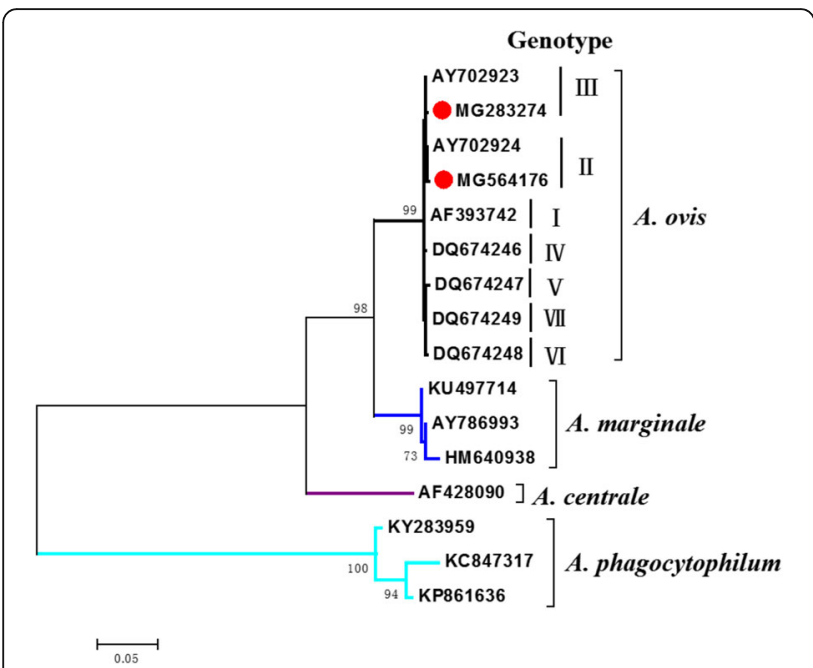

Fig. 2 Molecular phylogenetic analysis of A. ovis strains by application of the ML method to the msp4 gene sequence data. Evolutionary analyses were conducted in MEGA 7. Nucleotide sequence differences among the msp 4 gene sequences from different isolates of $A$. ovis confirmed seven genotypes [20]. Sequences of our specimens are marked with red circles

adult $M$. ovinus and four sequences from pupal $M$. ovinus) analyzed in 25 PCR amplicons.

Sequences of the two taxa obtained in this study having the highest similarity with the msp4 gene sequence of Anaplasma spp. in the GenBank database are listed in Table 1, both of which are $A$. ovis isolates. The phylogenetic analysis of msp4 confirmed that the obtained Anaplasma sp. was $A$. ovis (Fig. 2). Additionally, A. ovis isolates XJNJ (MG283274) and XJNJ2 (MG564176) were classified as A. ovis msp4 Genotypes II and III based on $\mathrm{A}^{360} \mathrm{~T}^{366} \mathrm{G}^{400} \mathrm{C}^{470} \mathrm{~T}^{522} \mathrm{~A}^{630} \mathrm{C}^{774}$ and $\mathrm{A}^{360} \mathrm{~T}^{366} \mathrm{G}^{400} \mathrm{~T}^{470} \mathrm{~T}^{522} \mathrm{~A}^{630} \mathrm{C}^{774}$, respectively (Fig. 3).

\section{Discussion}

The presence of $A$. ovis DNA in adult and pupal M. ovinus collected in South Xinjiang, China, was confirmed by conventional PCR and sequencing. The sequence variation in the msp4 gene among different A. ovis strains [20] confirmed that two genotypes of A. ovis were detected in this study.

The detection of $A$. ovis in $M$. ovinus has been reported previously [15]. Anaplasma ovis has also been discovered in adults of hippoboscid species (Lipoptena cervi), but not in the larvae and pupae [17]. Bartonella [4, 7], Arsenophonus and Wolbachia [7] can be transmitted vertically in M. ovinus. Both M. ovinus $[4,7,17]$ and L. cervi mediate vertical transmission of Bartonella [29]. Nevertheless, the vertical transmission of $A$. ovis via parasites belonging to the family Hippoboscidae (Diptera: Hippoboscoidea) has not been reported. To the best of our knowledge, this study provides the first molecular evidence for the presence of $A$. ovis DNA in pupal $M$. ovinus. Additionally, the detection of $A$. ovis DNA in $M$. ovinus has not been reported in China. Our study suggests that $A$. ovis may be transmitted vertically via $M$. ovinus, and that $M$. ovinus may serve as a potential vector for $A$. ovis.

The diseases caused by Anaplasma spp. are a global issue, among which $A$. ovis causes ovine anaplasmosis. First discovered in sheep in 1912, A. ovis is currently widely distributed in Africa, Europe, Asia, and the USA [24, 25]. In China, A. ovis was first found in 1982 in the Xinjiang Uygur Autonomous Region, followed by Liaoning Province. Subsequent studies revealed that $A$. ovis is widely distributed in China and is particularly prevalent in the northwest region [22, 25]. Anaplasma ovis mainly parasitizes sheep, goats, wild ruminants [30,31], cattle [28] and dogs [32]. Recently, an A. ovis variant was detected in a patient, indicating the zoonotic potential of this agent [33]. In addition, some sequences having the highest similarity with the msp4 gene sequence of the two $M$. ovinus-derived $A$. ovis isolates in this study were detected in the blood of sheep sampled in Xinjiang in 2012. Taken together, Xinjiang has been seriously infested with $A$. ovis. It has been confirmed that various ticks, belonging to the genus Ixodes, serve as biological vectors for the transmission of $A$. ovis in China [22]. Our study confirmed the transmission of $A$. ovis via $M$. ovinus in China. Furthermore, currently there are seven

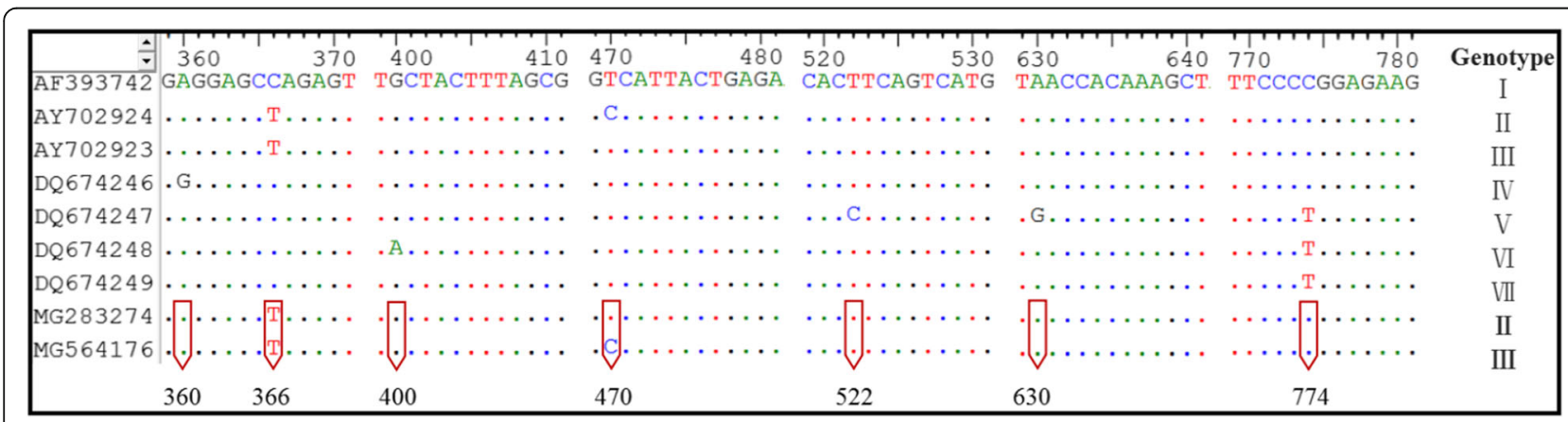

Fig. 3 Nucleotide sequence differences among the msp4 gene sequences from different isolates of $A$. ovis. The numbers represent the nucleotide positions starting at the translation initiation codon, adenine 
Anaplasma spp. in China, including the recently discovered A. capra [26, 34, 35]. Additionally, vertical transmission of A. ovis was confirmed in the present study. Thus, Anaplasma spp. require close attention because the above-mentioned situations and phenomena lead to anaplasmosis in humans or animals and cause unpredictably huge economic losses.

\section{Conclusions}

To our knowledge, this is the first report worldwide on the detection of $A$. ovis DNA in pupal M. ovinus, confirming the vertical transmission of $A$. ovis in $M$. ovinus and the potential of $M$. ovinus as the vector for $A$. ovis.

\section{Abbreviations \\ ML: Maximum-likelihood; PCR: Polymerase chain reaction}

\section{Acknowledgments}

Not applicable.

\section{Funding}

This study was funded by the National Natural Science Foundation of China (No. 31460655) and the open project of the Key Laboratory of Tarim Animal Husbandry Science and Technology, Xinjiang Production \& Construction Corps (No. HS201501 and No. HS201801).

\section{Availability of data and materials}

The msp4 sequences generated in this study were submitted to the GenBank database under the accession numbers MG283274 and MG564176.

\section{Authors' contributions}

$L Z$ and $Y H L$ conceived and designed the study and critically revised the manuscript. $L Z, X Q L$ and $L Y Z$ performed the sheep ked collection. $Y H L, F L$, $\mathrm{BH}$ and $\mathrm{KRL}$ conducted the laboratory experiments. All the authors read and approved the final manuscript.

\section{Ethics approval and consent to participate}

Ethical treatment of animals was practiced in this study; however, the relevant document number is not available at Tarim University. Permission was obtained from the farm owners before collection of the specimens.

\section{Consent for publication}

Not applicable.

\section{Competing interests}

The authors declare that they have no competing interests

\section{Author details}

${ }^{1}$ College of Animal Science, Tarim University, 705 Hongqiao South Road, Aral 843300, People's Republic of China. ${ }^{2}$ Key Laboratory of Tarim Animanl Husbandry Science and Technology of Xinjiang Production \& Construction Corps, 705 Hongqiao South Road, Aral 843300, People's Republic of China. ${ }^{3}$ Animal Loimia Controlling and Diagnostic Center of Aksu Region, Friendship Road, Aksu 843000, People's Republic of China.

Received: 22 December 2017 Accepted: 7 March 2018

Published online: 19 April 2018

\section{References}

1. Small RW. A review of Melophagus ovinus (L.), the sheep ked. Vet Parasitol. 2005;130:141-55.

2. $\quad$ Liu D, Wang YZ, Zhang H, Liu ZQ, Wureli HZ, Wang SW, et al. First report of Rickettsia raoultii and $R$. slovaca in Melophagus ovinus, the sheep ked. Parasit Vectors. 2016;9:600.

3. Duan DY, Liu H, Cheng TY, Wang YQ. Microbial population analysis of the midgut of Melophagus ovinus via high-throughput sequencing. Parasit Vectors. 2017;10:382.
4. Kumsa B, Parola P, Raoult D, Socolovschi C. Bartonella melophagi in Melophagus ovinus (sheep ked) collected from sheep in northern Oromia, Ethiopia. Comp Immunol Microbiol Infect Dis. 2014;37:69-76.

5. Chu CY, Jiang BG, Qiu EC, Zhang F, Zuo SQ, Yang H, et al. Borrelia burgdorferi sensu lato in sheep keds (Melophagus ovinus), Tibet China. Vet Microbiol. 2011;149:526-9.

6. Wu HS, Yang N, Ma SM, Chen HJ, Zheng Y, Ge RL. A survey of three zoonosis and ectoparasite of Tibetan antelopes. Chin Qinghai J Anim Vet Sci. 2010:40:21-2.

7. Wang YQ, Cheng TY, Duan DY. Identification of the microflora in the midgut and pupa of Melophagus ovinus. Chin Vet Sci. 2017:47:861-5.

8. Wang Y, Sun BJ, Yu CY, Ni X. Melophagus ovinus Linnaeus intercepted and captured from Canadian pickled goatskins at Linyi Port. Chin J Vector Bio Control. 2010;21:35.

9. Wang $W$. There are 4 eggs in the imported wool, Shaoxing intercepted exotic pest parasites. In: Shaoxing evening; 2017. http://zj.zjol.com.cn/news/ 554539. Accessed 12 Feb 2017

10. Bequaert J. A monograph of the Melophaginae, or ked-flies, of sheep, goats, deer and antelopes (Diptera, Hippoboscidae). Entomol Am. 1942:22:1-220.

11. Tetley JH. The sheep ked, Melophagus ovinus L. I Dissemination potential. Parasitology. 1958:48:353-63.

12. Izdebska JN. European bison arthropod parasites from closed Polish breeding facilities. Acta Parasitol. 2001:46:135-7.

13. Lassnig H, Prosl H, Hinterdorfer F. Parasites of the red fox (Vulpes vulpes) in Styria. Wien Tierarztl Monat. 1998:85:116-22.

14. Gibson W, Pilkington JG, Pemberton JM. Trypanosoma melophagium from the sheep ked Melophagus ovinus on the island of St Kilda. Parasitology. 2010;137:1799-804.

15. Hornok S, de la Fuente J, Biró N, Fernández de Mera IG, Meli ML, Elek V, et al. First molecular evidence of Anaplasma ovis and Rickettsia spp. in keds (Diptera: Hippoboscidae) of sheep and wild ruminants. Vector Borne Zoonotic Dis. 2011:11:1319-21.

16. Luedke AJ, Jochim MM, Bowne JG. Preliminary bluetongue transmission with the sheep ked Melophagus ovinus (L.). Can J Comp Med Vet Sci. 1965;29:229-31.

17. Halos L, Jamal T, Maillard R, Girard B, Guillot J, Chomel B, et al. Role of Hippoboscidae flies as potential vectors of Bartonella spp. infecting wild and domestic ruminants. Appl Environ Microbiol. 2004;70:6302-5.

18. Kosoy M, Bai Y, Enscore R, Rizzo MR, Bender S, Popov V, et al. Bartonella melophagi in blood of domestic sheep (Ovis aries) and sheep keds (Melophagus ovinus) from the southwestern US: cultures, genetic characterization, and ecological connections. Vet Microbiol. 2016;190:43-9.

19. Rudolf I, Betasova L, Bischof V, Venclikova K, Blazejova H, Mendel J, et al. Molecular survey of arthropod-borne pathogens in sheep keds (Melophagus ovinus), central Europe. Parasitol Res. 2016;115:3679-82.

20. de la Fuente J, Atkinson MW, Naranjo V, Fernández de Mera IG, Mangold AJ Keating KA, et al. Sequence analysis of the msp4 gene of Anaplasma ovis strains. Vet Microbiol. 2007:119:375-81.

21. Yin H, Luo JX. Ticks of small ruminants in China. Parasitol Res. 2007;101:187-9.

22. Ma ML, Liu ZJ, Sun M, Yang J, Guan G, Li Y, et al. Development and evaluation of a loop-mediated isothermal amplification method for rapid detection of Anaplasma ovis. J Clin Microbiol. 2011:49:2143-6.

23. Dumler JS, Barbet AF, Bekker CP, Dasch GA, Palmer GH, Ray SC, et al. Reorganization of genera in the families Rickettsiaceae and Anaplasmataceae in the order Rickettsiales: unification of some species of Ehrlichia with Anaplasma, Cowdria with Ehrlichia and Ehrlichia with Neorickettsia, descriptions of six new species combinations and designation of Ehrlichia equi and 'HGE agent' as subjective synonyms of Ehrlichia phagocytophila. Int J Syst Evol Microbiol. 2001;51:2145-65.

24. Renneker S, Abdo J, Salih DEA, Karagenc T, Bilgic H, Torina A, et al. Can Anaplasma ovis in small ruminants be neglected any longer? Transbound Emerg Dis. 2013;60:105-12.

25. Han R, Yang JF, Liu ZJ, Gao S, Niu QL, Hassan MA, et al. Characterization of Anaplasma ovis strains using the major surface protein 1a repeat sequences. Parasit Vectors. 2017:10:447

26. Yang JF, Han R, Niu QL, Liu ZJ, Guan G, Liu G, et al. Occurrence of four Anaplasma species with veterinary and public health significance in sheep, northwestern China. Ticks Tick Borne Dis. 2018;9:82-5.

27. Battilani M, De Arcangeli S, Balboni A, Dondi F. Genetic diversity and molecular epidemiology of Anaplasma. Infect Genet Evol. 2017:49:195-211.

28. Hornok S, Micsutka A, Fernández de Mera IG, Meli ML, Gönczi E, Tánczos B, et al. Fatal bovine anaplasmosis in a herd with new genotypes of 
Anaplasma marginale, Anaplasma ovis and concurrent haemoplasmosis. Res Vet Sci. 2012;92:30-5.

29. de Bruin A, van Leeuwen AD, Jahfari S, Takken W, Földvári M, Dremmel L, et al. Vertical transmission of Bartonella schoenbuchensis in Lipoptena cervi. Parasit Vectors. 2015;8:176.

30. Li Y, Chen Z, Liu Z, Liu J, Yang J, Li Q, et al. Molecular survey of Anaplasma and Ehrlichia of red deer and sika deer in Gansu, China in 2013. Transbound Emerg Dis. 2016;63:228-36.

31. Li Y, Chen Z, Liu Z, Liu J, Yang J, Li Q, et al. First report of Theileria and Anaplasma in the Mongolian gazelle, Procapra gutturosa. Parasit Vectors. 2014;7:614.

32. Cui $Y$, Yan $Y$, Wang $X$, Cao $S$, Zhang $Y$, Jian F, et al. First molecular evidence of mixed infections of Anaplasma species in dogs in Henan, China. Ticks Tick Borne Dis. 2017;8:283-9.

33. Chochlakis D, loannou I, Tselentis Y, Psaroulaki A. Human anaplasmosis and Anaplasma ovis variant. Emerg Infect Dis. 2010;16:1031-2.

34. Li H, Zheng YC, Ma L, Jia N, Jiang BG, Jiang RR, et al. Human infection with a novel tick-borne Anaplasma species in China: a surveillance study. Lancet Infect Dis. 2015;15:663-70.

35. Yang J, Li Y, Liu Z, Liu J, Niu Q, Ren Q, et al. Molecular detection and characterization of Anaplasma spp. in sheep and cattle from Xinjiang, northwest China. Parasit Vectors. 2015;8:108.

Submit your next manuscript to BioMed Central and we will help you at every step:

- We accept pre-submission inquiries

- Our selector tool helps you to find the most relevant journal

- We provide round the clock customer support

- Convenient online submission

- Thorough peer review

- Inclusion in PubMed and all major indexing services

- Maximum visibility for your research

Submit your manuscript at www.biomedcentral.com/submit
Biomed Central 